\title{
シリーズ COVID-19(5)
}

\section{妊娠とコロナウイルス感染症 \\ 早川 智相澤 (小峯) 志保子 高田 和秀 \\ 日本大学医学部病態病理学系微生物学分野}

(J. Nihon Univ. Med. Ass., 2021; 80 (4): 157-159)

要旨 COVID-19 のパンデミックは，医学のみならず 社会経済的に世界的問題となっている。当初，若年者は SARS-CoV-2 に感染しても，無症状あるいは軽症ですむ といわれていたが，主な流行株が $\delta$ 株に置き換わるにつ れて, 若年者の感染者が増加し, 中には重症化するケー スも増えてきた。 それに伴い， 2021 年 7 月以降，妊婦 の感染者数も急増している，幸いなことに SARS-CoV-2 は風疹やジカ熱のような催奇性の報告は無いが, 妊娠中 に重症化すると，母体の治療のために予定日よりも前で あっても帝王切開で早期に分婏とせざるを得ない場合も ある，子宮内での胎児への感染は極めて稀であるが，出 生後に水平感染で感染するリスクはある，現在，全世界 で新型コロナウイルスワクチンの接種が進められている. 妊婦に対するワクチンの有効性や安全性が明らかになっ たため，妊婦や娃娠を希望する人への接種も推奨されて いる。しかし, 安全性への不安などを理由に接種を希望 しない人も多い，COVID-19 に感染した妊婦に対して投 与できる薬剤は限られており, ワクチンも含めて厳重か つ積極的な感染予防が重要である.

\section{妊娠と COVID-19}

今回のパンデミックが始まって, 多くの人々が心配し たのは妊婦に及ぼす影響である。10 年前の新型インフ ルエンザ同様に妊婦がより重症化しやすいのではないか という問題に加えて, 数年前のジカ熱子宮内感染による 小頭症や，予防接種率の低下による先天風疹症候群の増 加は記憶に新しい，当初，妊婦は「免疫力」が低下する から重症化しやすいという不正確な情報が流れたが，そ ういったことはなく我が国に打ける全体としての生命予 後は非妊婦と変わらない，たた，妊娠後期に感染する と, 横隔膜の挙上による肺の圧迫や血液凝固能の六進に よって重症化しやすいことから，母児双方の管理に苦虑 することがある，国内外の臨床統計から，妊婦が特に COVID-19に感染しやすいということはなく，妊娠中に 感染しても全体としての重症化率や死亡率は同年齢の女 性と変わらないことが明らかになった1)。また，妊娠初 期・中期の感染で胎児に先天異常を起こすという報告も ない. しかし, 妊娠後期に感染すると, 早産率が高まり,
患者本人も一部は重症化することが報告されている，日 本産科婦人科学会と日本産婦人科感染症学会に 2021 年 4 月 19 日までに登録された COVID-19 と確定診断され た妊婦 61 例中, 重症 2 例 (3.2\%) (人工呼吸器, ECMO 各 1 例), 酸素投与を受けた患者 6 例 $(9.8 \%)$, 軽症 53 例（87\%）であった。母体死亡や子宮内感染は 1 例も見 られなかった。重症化した患者は気管支喘息，妊娠性糖 尿病などの合併がみられた。欧米ではこれに加えて，人 種や喫煙歴, 妊娠高血圧症候群, 肥満, 血栓傾向などが リスク因子として報告されている。海外からの報告によ ると, 18 か国 43 施設に扔ける COVID-19 感染妊婦, 新 生児の予後解析では, COVID-19 罹患妊婦はそうでない 妊婦に比較し, 集中治療室入室（RR, $5.04 ； 95 \%$ CI, 3.13-8.10), 母体死亡率（RR，22.3;95\% CI，2.88-172）, 早産 $(\mathrm{RR}, 1.59 ; 95 \% \mathrm{CI}, 1.30-1.94)$, 医学的適応早産 (RR， $1.97 ; 95 \% \mathrm{CI}, 1.56-2.51)$, 重度新生児罹患率 $(\mathrm{RR}$, $2.66 ； 95 \%$ CI, 1.69-4.18), 重度周産期罹患率 - 死亡率 （RR，2.14；95\% CI，1.66-2.75）と母児ともに重症化· 死亡のリスクがあるとしている2). これらの知見より， 日本産科婦人科学会, 日本産婦人科医会, 日本産婦人科 感染症学会では妊婦に対して積極的なワクチン接種を推 奨している。我が国では 2020 年 5 月という早い時期に 与野党の協力で妊婦に扔ける感染回避策の徹底と, 必要 に応じた配置転換や休業が可能となった。興味深いこと に多くの COVID-19 感染妊婦では胎盤に SARS-CoV-2の 局在が認められても母子感染は成立せず，有効な胎盤関 門が機能していると考えられる3゙.

\section{COVID-19 と生殖医療}

産婦人科診療においてコロナ流行下でも妊娠出産は待 つことができず，また悪性腫瘍の患者さんも治療の遅れ は生命予後に繋がるので待つ事は出来ない，その点，不 妊症は直接本人の生命予後に関わらない。2020年 3 月 17 日, 米国生殖医療学会 (ASRM) は, 妊娠を目的とし た新たな治療サイクルの開始を停止することを勧告し, 日本生殖医学会も同様の锥告を行った。しかしながら, 数か月から年余にわたる生殖医療の遅れは貴重な妊娠機 会を奪うことになる，現在では，不妊治療を受ける患者 
さんのなかで妊娠可能な残り時間の限られた方や卵巣予 備能の低い方から優先順位をつけて治療が行われてい $ろ^{4)}$.

\section{妊婦，妊娠を希望する女性へのワクチン接種}

COVID-19 パンデミック制圧への切り札となるのはワ クチン接種である。わが国では 2021 年 3 月から，まず は医療従事者へ，ついで 65 歳以上の高齢者，基礎疾患 を有する方・高齢者施設等と接種が進められた。 5 月下 旬には自衛隊や自治体における大規模接種会場での接種 が始まり，6月下旬から企業や大学などでの職域接種が スタートした。しかし，2021 年 8 月 16 日現在，2回の ワクチン接種が完了したのは日本の総人口の $37.4 \%$ にと どまっており，さらなるワクチンの普及が急がれる。妊 婦に対しては，当初安全性が確立していないことから， 積極的な対象から除外されてきた。しかしながら，諸外 国で多数の妊婦に接種が行われ，副反応の程度や頻度が 非妊婦と変わらないこと，胎坚や母体に対する致命的な 有害事象がないことから，ワクチン接種のメリットがデ メリットを上回ると考えられるに至った。日本産科婦人 科学会と日本産婦人科感染症学会は妊産婦さん向けに, 「COVID-19 ワクチン接種についてのお知らせ」を2021 年 1 月に公開し，5月に改訂第 2 版を出した ${ }^{5)}$. その後 の感染状況から，日本産婦人科医会を加えた 3 学会合同 で新たなお知らせを 6 月 17 日に公開し，8月14日に改 訂第 2 版を公開した ${ }^{6)}$ 。諸外国でも，当初は慎重な意見 があったが，米国産科婦人科学会 (ACOG) と母体胎児医 学会 (SMFM) は, 7 月 30 日付で感染, 重症化, 死亡の リスクを避けるため妊娠の時期，出産後を問わず，すべ ての妊婦にCOVID-19 ワクチンを接種することを強く推 奨するというコメントを出した ${ }^{7)}$ 。現時点では日本国内 で接種されているのは mRNA ワクチン（ファイザー社, モデルナ社）のみであるが，諸外国でこれらのワクチン の接種後に流産. 早産, 胎児発育遅延, 先天奇形, 新生 児死亡が起きる確率はワクチン非接種者と変わらなかっ た.さらに, mRNAワクチン接種後には母体の血中で 中和抗体価が上昇し， IgG が胎盤を介して胎児に移行す るため, 出生した時の早期の感染防御に有効である. 米国の単一施設で，合計 131 名（妊婦 84 名，授乳中 31 名, 非妊婦 16 名）の女性接種者のワクチン応答（抗体 価）を検討したところ，妊婦か非妊婦に関係なく，全て の群で抗体価には有意差なく，いずれの場合でも自然感 染例より抗体価は有意に上昇し，全例で臍帯血および母 乳中に中和抗体が存在したという ${ }^{8)}$. 当初，3学会では 器官形成期の妊娠 12 週までは，偶発的な胎児異常の発 生との識別に混乱をきたす恐れがあるため接種を避ける ようにとしていたが，催奇形性がないことが判明した ため，6月以降，この制限は撤廃している。一方では, SNS を中心に mRNA ワクチンで不妊になる，というデ
マが拡散している。これまでも，ワクチンと不妊の関連 はしばしば騒がれることがあったが，既存のワクチンで も接種によって不妊となった例はない。ラットを用いた 動物実験で COVID-19 mRNA ワクチン接種群と非接種 群で妊娠率, 胎仔数, 胎仔の大きさに差はなかった9). ファイザー社の元社員が，胎盤形成に必須のタンパク synsytin-1 と SARS-CoV-2 の spike protein のアミノ酸配 列が類似しているため，抗体が synsytin-1 を認識し，胎 盤形成を阻害する可能性がある，と主張したが，両者の アミノ酸配列を比較すると，相同性はなく全くのデマで ある。これらの誤った情報に答えるために，日本産婦人 科感染症学会では一般の人向けに Q\&A「女性のみなさ まへ 新型コロナウイルスワクチン（mRNA ワクチン） Q\&A」を作成し，ホームページ上で公開している ${ }^{10)}$.

\section{妊婦における治療薬}

妊婦における COVID-19 感染者の管理は，通常の成人 に準ずるが，アビガン ${ }^{\circledR}$ (ファビビラビル）は催奇形性 があるため，妊婦に対しては使用禁忌である，服用終了 後も生殖毒性があるため, 生殖医療を受けている患者さ んのみならず，生殖年齢にある男女とも服用終了後 2 週 間は避妊を要する。ベクルリー ${ }^{\circledR}$ (レムデシビル）とロ ナプリーブ®（カシリビマブ/イムデビマブ）は，有益性 投与であるが，オルミエント ${ }^{\circledR}$ (バリシチニブ）は催奇 性があり禁忌である ${ }^{11)}$ ，イベルメクチンには催奇性があ るため予防あるいは治療投与は妊娠の有無に関係なく推 奨されない。妊婦では凝固傾向が強いので COVID-19 感 染者には積極的に抗凝固療法を行うが，抗リン脂質抗体 症候群や妊娠高血圧症候群では特に注意を要する。

\section{感染終息と今後の見通し}

COVID-19 の発生は社会的経済的に全世界に大打撃を 与え，いまだ世界は回復の途上にある。しかし，短い期 間に病原体の同定から免疫病態の解明，さらにワクチン やモノクローナル抗体カクテル療法などの開発がなされ たことは，現代医学に対する社会の信頼を強固にしてく れる。感染が終息すれば経済活動は回復するはずだが, 時差出勤や在宅勤務，オンライン会議やオンライン授業 などの三密回避はこのまま社会のスタンダードとなり， 回し飲みや自分の箸で大皿をつつく，よく知らない相手 との casual sex などは廃れてゆくであろう。社会におけ るグローバル化の流れ自体は変わらないが，実際の人の 行き来よりもオンラインによる情報交換が一般的となる. 産婦人科診療では，感染妊婦の入院管理や分娩，新生児 管理，病床逼迫への対応など，施設・人員ともに余裕の ない現状が浮き彫りになってきた，特に医療体制の脆弱 な地方では COVID-19 以外の疾患も含めた「医療崩壊」 が現実のものとなっている。（2021 年 8 月，千葉県で中 等症の COVID-19 感染で自宅療養中の妊婦が早産し, 新 
生児が死に至るという痛ましい事例があった）今後, いつ何時新型コロナウイルス感染症よりもさらに致死性 や感染性が高い新興感染症が発生するかもわからない. 我々医学者は今回のパンデミックの教訓をもとに「備え よ常に (Be prepared)」という Robert Stephenson Smyth Baden-Powell 卿（ボーイスカウトの創設者）のモットー を念頭に置きたいものである。

\section{文献}

1) Hayakawa $\mathrm{S}$, Komine-Aizawa S, Mor GG. Covid-19 pandemic and pregnancy. J Obstet Gynaecol Res 2020; 46(10): 1958 1966.

2) Villar J, Ariff S, Gunier RB, et al. Maternal and Neonatal Morbidity and Mortality Among Pregnant Women With and Without COVID-19 Infection: The INTERCOVID Multinational Cohort Study. JAMA Pediatr 2021; 175(8): 817-826.

3) Komine-Aizawa $S$, Takada K, Hayakawa S. Placental barrier against COVID-19. Placenta 2020; 99: 45-49.

4) 厚生労働省 新型コロナウイルス感染症 (COVID-19) 診 療の手引き・第 5.2 版. https://www.mhlw.go.jp/content/ 000815065.pdf.

5) Hayakawa S, Komine-Aizawa S, Takada K, et al. Anti-SARS-
CoV-2 vaccination strategy for pregnant women in Japan. $J$ Obstet Gynaecol Res 2021, doi:10.1111/jog.14748.

6）妊産婦のみなさまへ 新型コロナウイルスワクチンに ついて. http://jsidog.kenkyuukai.jp/images/sys/information/ 20210618085642-AA2AB263D1579515C925BB40A60A311 585CF581972A6A250A9791298AF8EF189.pdf.

7) https://www.acog.org/news/news-releases/2021/07/acog-smfmrecommend-covid-19-vaccination-for-pregnant-individuals.

8) Gray KJ, Bordt EA, Atyeo C, et al. Coronavirus disease 2019 vaccine response in pregnant and lactating women: a cohort study. Am J Obstet Gynecol 2021, S0002-9378(21)00187-3.

9) Bowman CJ, Bouressam M, Campion SN, et al. Lack of effects on female fertility and prenatal and postnatal offspring development in rats with BNT162b2, a mRNA-based COVID19 vaccine. Reprod Toxicol (IF: 3.121; Q2) 2021; 103: 28-35, doi:10.1016/j.reprotox.2021.05.007.

10）女性のみなさまへ 新型コロナウイルスワクチン (mRNA ワクチン）Q \& A. http://jsidog.kenkyuukai.jp/images/sys/ information/20210721190701-57649255BD0A756A3E48F8 FEB3D9AC5B55FDB9F89BB2D2EFC9C5AA308C98CC3D. pdf.

11) 日本医学会連合 COVID-19 expert opinion 第 3 版 (2021 年 8 月）印刷中. 